\title{
GERAKAN MASYARAKAT HINDU MENOLAK PENGAYOMAN IDEOLOGI DAN ORGANISASI TRANSNASIONAL SAMPRADAYA DI PARISADA HINDU DHARMA INDONESIA (PHDI)
}

\author{
Oleh: \\ Ida Ayu Made Gayatri \\ dayugayatrimantra@gmail.com
Prodi Manajemen, Fakultas Ekonomi dan Bisnis Universitas Ngurah Rai
Denpasar 80238 Indonesia

Proses Review 5-15 A*pril, Dinyatakan Lolos 20 April

\begin{abstract}
This article identifies the impact of the dynamics of dissociative social interaction in the form of horizontal conflicts between community groups from August 2020 to April 2021 in Bali. This research applied a theoretical approach to social movements and social mobilization. The data was collected in qualitative research with several techniques as participatory observation, in-depth interviews and library research. The results of this study indicate the impact of propaganda and actions from the association of Gema Hindu, namely: 1) aims at urging PHDI to revoke the cover letter for the sampradaya of Hare Krishna of the ISKCON, Sai Baba, and other sampradaya;2) successfully obtains broad sympathy with the support of the Governor, DPRD, Traditional Village Council and PHDI of Bali Province and the Hindu community nationally; 3) producing Joint Decree (SKB) of the PHDI Bali Province and MDA Bali Province; 4) produce pre-emptive, preventive and repressive law enforcement actions in preventing religious blasphemy and fundamentalism as well as religious radicalization in the PHDI and desa adat as part of community participation in the defense of the Republic of Indonesia and the Pancasila ideology.
\end{abstract}

Keywords: transnational, sampradaya, social movements.

\begin{abstract}
Abstrak
Artikel ini mengidentifikasi dampak dari dinamika interaksi sosial disosiatif berupa konflik horizontal antarkelompok masyarakat sejak Agustus 2020 hingga April 2021 di Bali. Penelitian menggunakan pendekatan teoritik gerakan sosial dan mobilisasi sosial. Metode pengumpulan data dalam penelitian kualitatif ini yaitu observasi partisipatif, wawancara mendalam dan studi pustaka.
\end{abstract}


Hasil penelitian ini menunjukkan dampak propaganda dan aksi dari Gema Hindu yaitu:1) ditujukan untuk mendesak PHDI mencabut surat pengayoman untuk sampradaya Hare Krishna ISKCON, Sai Baba dan sampradaya lainnya; 2) berhasil mendapat simpati secara luas dengan adanya dukungan Gubernur, DPRD, Majelis Desa Adat dan PHDI Provinsi Bali dan masyarakat Hindu secara nasional; 3) menghasilkan Surat Keputusan Bersama (SKB) PHDI Provinsi Bali dan MDA Provinsi Bali; 4) menghasilkan tindakan penegakan hukum secara pre-emtif, preventif dan represif dalam pencegahan penistaan agama dan fundamentalisme serta radikalisasi agama di PHDI dan desa adat sebagai bagian dari partisipasi masyarakat dalam pertahanan NKRI dan ideologi Pancasila.

Kata kunci: transnasional, sampradaya, gerakan sosial.

\section{PENDAHULUAN}

Gerakan Masyarakat Hindu (Gema Hindu) ini merupakan manifestasi adanya dinamika interaksi sosial disosiatif berupa konflik horizontal antarkelompok masyarakat sejak Agustus 2020 hingga April 2021 di Bali. Gerakan ini ditujukan agar penistaan agama Hindu ditindak secara hukum dan eksistensi ideologi dan organisasi transnasional sampradaya keluar dari pengayoman PHDI. Aksi mereka juga menuntut eksistensi sampradaya dipindahkan pengayomannya kepada tim Pengawas Aliran Kepercayaaan Masyarakat (PAKEM) dan Kementerian Kebudayaan. Pengayoman PHDI terhadap ideologi dan organisasi transnasional sampradaya dianggap sebagai kebijakan dan keputusan yang keliru. Sasaran tugas dari PHDI seharusnya memusatkan perhatian pada pengayoman masyarakat Hindu dengan kearifan budaya nusantara di Indonesia sehingga pengayoman PHDI terhadap ideologi dan organisasi transnasional sampradaya harus dicabut atau dibatalkan.

Eksistensi ideologi dan organisasi transnasional dengan istilah "sampradaya bernafaskan Hindu" di tubuh PHDI diatur dalam Kesepakatan Bersama pada 3 November 2001, penetapan pasal 41 AD/ART PHDI hasil Mahasabha VIII tahun 2016 tentang kerjasama dan Surat Nomor: 413/ Parisadha P/IV 2016 ditandatangani Mayjen TNI (Purn) Sang Nyoman Suwisma selaku ketua harian PHDI Pusat untuk memberikan pengayoman kepada ISKCON/Hare Krishna.

Pada 3 November 2001 PHDI Pusat telah membuat kesepakatan bersama dengan beberapa sampradaya, diantaranya: 1) Yayasan Sri Satya Sai Baba Indonesia; 2) Dewi Mandir; 3) Yayasan keluarga Besar Chinamaya Jakarta; 4) Yayasan Radha Govinda;5) Guru Dwara Sikh Temple; 6) Paguyubann Majapahid. Surat kesepakatan ini ditandatangani ketua harian PHDI Pusat I Nyoman Suwandha,SH. Dan Bimas Hindu dan Budha Drs. I Wayan Suarjaya,M.Si.

Dari beberapa ideologi dan organisasi sampradaya yang diayomi PHDI ini, Hare Krishna dan Sai Baba menjadi kontroversial akibat adanya polemik atau konflik sosial dalam bentuk penistaan agama dan apropiasi budaya yang ditimbulkan para pengikut atau bhakta. Fakta menunjukkan Kejaksaan Agung RI menerbitkan Surat Keputusan Kejaksaan Agung RI no 107/ JA/5/1984 (SK 107/1984) tentang Larangan Peredaran Barang-Barang Cetakan yang memuat Ajaran Kepercayaan Hare Krsna di Seluruh Indonesia. Meskipun SK 107/1984 ini masih berlaku, namun pada kenyataannya, ajaran Hare Krishna ini disebarkan kepada masyarakat melalui distribusi buku agama Hindu disusupkan dalam kurikulum Pendidikan Agama Hindu di sekolah-sekolah secara nasional. Buku Bhagawad Gita Menurut Aslinya Karangan Srila Prabupada yang isinya manipulatif karena banyak diubah isinya serta telah disosialisasikan oleh bhakta Hare Krishna/ ISCKON dan bahkan oleh oknum elit PHDI secara luas. Bhakta Hare Krishna/ISKCON juga mendeskriditkan praktik keagamaan Hindu Bali sebagai praktik keagamaan yang tidak bersumber dari Veda.

Apropiasi budaya merupakan perampasan budaya yang dilakukan oleh suatu budaya tertentu tanpa ijin pemilik budaya yang 
bersangkutan serta menggunakan atribut budaya tanpa memahami esensi budaya dari pemilik budaya yang sah sehingga dapat menghilangkan kesakralan dari budaya asli. Richard A. Rogers dalam jurnal communication theory menyatakan apropriasi budaya menggunakan simbol artefak, genre ritual, atau teknologi budaya atau teknologi budaya oleh anggota budaya lain (Ansharulloh, 2018).

Perampasan budaya dapat bersifat eksploitatif dan terdistorsi sebagai pajangan semata dinilai sebagai bentuk kamuflase. Apropriasi budaya seperti ini tidak mencerminkan kesopanan hingga menjadi bentuk penistaan terutama ketika ditujukan terhadap praktik budaya keagamaan. Dalam konteks apropiasi budaya ini teridentifikasi pengikut Sai Baba meletakkan foto Sai Baba di padmasana yang dianggap sebagai penistaan simbol agama Hindu. Padmasana adalah simbol pemujaan terhadap Ida Sang Hyang Widhi Wasa, Tuhan yang Maha Esa. Foto untuk memuja Sai Baba sebagai Tuhan yang diletakkan di Padmasana bertentangan dengan keyakinan umat Hindu di Indoensia yang tidak men-Tuhankan manusia. Sai Baba juga telah mencampuradukkan keyakinan agama yang berbeda dalam ajaran organisasinya yang dianggap gado-gado agama (sinkretisme agama) dengan jargon cinta kasih universal dan toleransi.

Pada peta google map ditemukan beberapa afiliasi organisasi sampradaya ISKCON menggunakan istilah manipulatif dengan menggunakan kata pura yaitu tempat ibadah umat Hindu untuk menyebut mandir dan ashram mereka, seperti: Pura Jaganath Gaurangga Mandir, Sri_sri Radha Rasevara Ashram, Sri-Sri Radha Kunjavihari temple dan Pura Sri Sri Krishna Balarama mandir. Demikian pula penempatan arca Srila Prabupada oleh pengikut Hare Krishna/ISKCON pada pelangkiran (altar mini untuk pemujaan Tuhan dan dewa-dewa) dan sebagai tindakan yang tidak pantas. ISCKON juga melakukan ritual di berbagai pura yang disakralkan umat Hindu Bali secara tidak pantas dan tidak mengikuti adat istiadat peribatan yang semestinya, seperti yang terjadi di Pura Menjangan dalam acara Jaganath Boat Tirtayatra pada tahun 2017 yang menjadi viral di media sosial.

Dalam Anggaran Dasar (AD) PHDI Ketetapan No: II/TAP/Mahasabha IX/2016 pada BAB X Hubungan Antar Organisasi pasal 41 ayat (1) berbunyi: Parisada Hindu Dharma Indonesia berkewajiban mengayomi setiap sampradaya yang berbentuk organisasi, forum, Lembaga, badan, dan yayasan yang bernafaskan Hindu yang mendaftar ke Parisada Hindu Dharma Indonesia.

Dalam zoominar yang diselenggarakan GKHN pada 14 Agustus 2020, Sang Nyoman Suwisma sebagai nasarasumber menyatakan sangat menyesal menerbitkan surat pengayoman untuk Hare Krishna ISCKON. Mantan Ketua harian PHDI Pusat ini juga meminta maaf secara tertulis kepada umat hindu serta meminta ketua harian PHDI berikutnya yaitu Wisnu Bawa Tenaya untuk mencabut surat keputusan pengayoman terhadap ISCKON. Hanya saja permintaan dari Sang Nyoman Suwisma dan tuntutan Masyarakat Hindu tidak mendapat sambutan dari PHDI Pusat.

Pondasi argumentasi penolakan masyarakat Hindu terhadap ideologi dan organisasi transnasional sampradaya sebagai berikut: pertama, ideologi sampradaya merupakan sistem kepercayaan dan agama tersendiri yang di luar negeri juga dikenal sebagai agama baru dengan istilah new age movement. Jargon adiluhung sebagai bagian dari marketing religion yang ditawarkan gerakan agama era baru ini berupa semangat persaudaraan universal (fraternity), persamaan semua agama (equality), kebebasan (liberty) dan kemanusiaan. Gerakan agama dan aliran kebatinan atau sinkretisme semacam ini mencampuradukkan beberapa kepercayaan dan umat, menggunakan teknik yoga dan meditasi, mistik tasawuf, dan kultus-kultus individu yang ditopang dengan sikap agama turistik atau "tourist of religion" (Fadhil, 2014).

Hare Krishna ISCKON, Sai Baba dan Sikh di luar negeri merupakan organisasi transnasional keagamaan dalam kegiatan spiritual. Ketiga organisasi transnasional sampradaya ini menjadikan guru spiritual atau kerohaniannya sebagai Tuhan yang Maha Esa. Hal ini dianggap tidak sesuai dengan nilai dan norma dalam praktik keagamaan Hindu di Indonesia yang 
tidak menganut ajaran men-Tuhan-kan manusia. Selain itu pernyataan guru dan dokumen garis perguruan menunjukkan mereka tidak berafiliasi dengan Hindu.

ISCKON atau Hare Krishna didirikan di Amerika pada tahun 1966 oleh Abhay Charan De, atau Bhaktivendanta Swami Prabhupada atau Srila Prabupada. Pada Hare Krishna, Sri Caitanya Mahaprabhu yang lahir di Nadiya India pada 18 Februari 1486 dipuja sebagai Tuhan Krishna. Sedangkan, Prabhu Nityananda kawan dari Caitanya Mahaprabhu dipuja sebagai Tuhan Krishna Balaram. Di Indonesia organisasi ini sempat bernama Sampradaya Kesadaran Krishna Indonesia (SAKHHI). Pada tahun 2015 telah menggunakan nama Perkumpulan ISKCON Indonesia yang merupakan afiliasi dari beberapa ashram. Srila Prabhupada sendiri menyatakan Hare Krishna/ISKCON bukan Hindu (Prabhupada, 2014). Governing Body Commision (GBC) merupakan manajerial tertinggi ISCKON (Sukkanah, 2017). GBC berkedudukan di New York dan Mayapur. ISCKON di Bali pecah menjadi dua kelompok dengan manajerial yang berbeda yaitu ISKCON SAKKHI dan Krishna Balaram.

Berdasarkan data dari website ISCKON centers dinyatakan beberapa ashram Hare Krishna di Bali yang sudah mendapatkan ijin dari badan pemerintahan ISKCON/Governing Body Commisson (GBC ISKCON) yaitu : 1) Krishna Balaram (Kesiman, Denpasar Timur) 2) Jagannatha Gaurangga Mandir (Jalan Tukad Balian Sidakarya Denpasar Selatan); 3) Kiskendha Krisna Loka Ashram (Banjar Wani, Gadungan Selemadeg Tabanan);4) Nagar Sankritana Mandir (Pudak Penyaringan Mendoyo Jembrana);5) Sri Nitai Gauracanda Ashram (jl Gempol Buleleng); 6) Sri-Sri Radha Madhawa Ashram (Desa Siangan Gianyar); 7) Sri-Sri Radha Kunjavihari Ashram (Banjar Celuk, Paksebali Klungkung) ; 8) Sri-Sri Radha Rasesvara Ashram (Banjar Dualang Abiansemal Badung); 9) Sri-Sri Nitai Gaurangga ashram (Banjar Sayan Baleran Desa Werdhi Buana Mengwi).

Agama Sikh muncul pertama kali di Punjab pada tahun 1469 didirikan oleh Guru Nanak Dev atau Nanak Dev Ji yang memadukan ajaran Hindu dan Islam. Ada 10 tokoh yang dianggap nabi dan yang terakhir disebut dengan Guru
Gobind Singh. Ranjit Singh pemuka agama Sikh di Indonesia menyatakan penganut Sikh bukan penganut Hindu. Sikh merupakan agama tersendiri, penganut monoteisme Ketuhanan Yang Esa yang disebut dengan Ek-Onkar, punya aksara tersendiri dan punya pengikut sendiri, kitab sucinya lima sufi yang memiliki tasawuf (Kumparan, 2017). Pendiri agama Sikh, Guru Nanak Dev mengatakan bahwa Sikh bukan Hindu dan bukan Islam, serta memiliki 10 guru yang sangat dihormati yaitu : 1) Nanak Dev Ji; 2) Anggada Dev; 3)Amar Das; 4) Ram Das; 5) Arjun Dev Ji; 6) Har Gobind ; 7) Har Rai; 8) Har Krishnan; 9 Tegh Bahadur; 10) Gobind Singh (Febryani, 2020).

Pada organisasi Sai Baba, dikenal dua tokoh, yaitu Sai Baba dari Sirdi dipercaya lahir pada 28 September 1835 dan Sri Satya Sai Baba lahir di desa Puttaparthi 23 November 1926. Ajaran Sri Satya Sai Baba di Indonesia dikembangkan dalam organisasi Sai Studi Group Indonesia (SSG) atau Sai Devotional Group (SDG). SSGI bukan organisasi keagamaan tetapi organisasi yang bersifat sosial dan spiritual (M.Nuh, 2017). $\mathrm{Hal}$ ini tertuang dalam anggaran dasar/AD Bab II dan dalam anggaran rumah tangga/ART disebutkan tujuan orgisasi adalah suatu Lembaga tempat mempelajari,menghayati, dan mengamalkan wacana-wacana Bhagawan Sri Sathya Sai Baba.

Argumentasi kedua, ideologi dan organisasi transnasional sampradaya diyakini mensubversi tatanan sosial, mengikis identitas jati diri bangsa dan memicu konflik laten hingga manifest. Ideologi dan organisasi transnasional telah menimbulkan kekisruhan yang memicu konflik laten hingga konfik manifest akibat ideologi (ajaran) dan mencampuradukkan agama dan umat beragama.

Fakta sosial menunjukkan Sai Baba dianggap mencampuradukkan agama-agama dicoret dari organisasi keagamaan di departemen agama (Tempo, 1994). Selain itu eksistensi dari SSGI ini memiliki keterkaitan dengan keberadaan Veda Poshana Ashram (VPA) di Bali (Budiasa, 2016). Keberadaan VPA menjadi sorotan karena dituding melakukan sejumlah pelanggaran yang tidak sesuai dengan aturan dari PHDI. Beberapa pelanggaran yang dilakukan VPA yaitu:1) menggunakan alamat PHDI sebagai sekretariat 
organisasi dalam kepala surat/kop surat organisasi;2) pelaksanaan diksa massal dan sulinggihnya yang tidak sesuai dengan aturan normatif yang berlaku di masyarakat dan PHDI. Gema Hindu menuding PHDI telah memfasilitasi VPA dengan memberikan sekretariat terhadap VPA namun tudingan ini kemudian dibantah oleh Ketua PHDI dalam Zoominar yang diselenggarakan GKHN dengan menyatakan bahwa penggunaan alamat PHDI sebagai sekretariat VPA adalah tanpa sepengetahuan dan seijin PHDI.

VPA melakukan diksa massal sulinggih pada tahun 2005, 2009, 2012 hingga tahun 2015 telah melahirkan 209 pandita, acharya, hotri dan hotraka yang mendapatkan resistensi dari masyarakat karena dianggap tidak sesuai dengan 'uger-uger" (aneh dan tidak biasa), tidak sinergis dengan kondisi sosial yang masih menganut pakem tradisional (VPA, 2018). Praktik ritual nyeleneh yang dilakukan dan menjadi ciri khas dari sulinggih VPA yang bergelar diksa dengan menyisipkan nama "Agni" yaitu melaksanakan ritual agnihotra yang telah dilarang di Bali sejak masa pemerintahan Dalem Waturenggong karena tidak sesuai dengan dresta (nilai dan norma) Bali.

PHDI Provinsi Bali menyatakan praktik diksa (penasbihan) sulinggih (ulama) secara massal yang dilakukan VPA bertentangan dengan aturan normatif yang berlaku, tanpa sepengetahuan PHDI atau tidak terdaftar di PHDI Provinsi Bali. Ketua PHDI Provinsi Bali menyatakan bahwa diksa hanya dapat dilakukan satu guru nabe kepada satu calon sulinggih, bukan satu guru nabe men-diksa banyak sulinggih. Selain itu, guru nabe yang dimaksud adalah nabe napak (yang membaptis dan mengesahkan), nabe waktra (yang memberikan pengajaran muput atau pelaksanaan ritual, menghapal mantra dan sebagainya) dan nabe saksi yang memberikan kesaksian calon sulinggih atau sang diksita yang sudah pantas didiksa (Tribun, 2021).

Kemarahan masyarakat Hindu di Bali memuncak karena adanya oknum sulinggih instan bernama Ida Bhagawan Rsi Agung Dwi Raka Sidi Mantra atau I Wayan Mahardika melakukan pelecehan seksual atau pencabulan (Kompas, 2021). Perilaku oknum sulinggih ini dituding sebagai dampak dari diksa massal yang dianggap tidak sesuai dengan nilai dan norma sosial di Bali dan kelemahan dari PHDI dalam mengawasi proses diksa massal yang dilakukan organisasi sampradaya. Gema Hindu menuding diksa sulinggih massal ini merusak tatanan sosial dan dirancang sebagai strategi untuk memenangkan suara sulinggih sampradaya pada sabha pandita atau pertemuan ulama pada Mahasabha PHDI serta dalam membuat beragam kebijakan untuk umat Hindu terutama untuk kepentingan eksistensi dan kepentingan politik sampradaya menjadi ajeg.

Akumulasi Gerakan Masyarakat Hindu ini mencapai puncaknya dengan peristiwa penutupan Asram Krishna Balaram di Padang Galak oleh Bendesa Adat dan prajuru (pengurus) Desa Adat Kesiman, didampingi pecalang dan disaksikan Kepolisian RI pada 18 April 2021. Penutupan dilakukan karena sejumlah pelanggaran yang dilakukan di ashram Krishna Balaram, yaitu :1) bhakta (pengikut ajaran) yang tinggal di ashram bukan warga Kesiman; 2) keberadaan bhakta tidak terdaftar sebagai krama tamiu (pendatang) di Desa Adat Kesiman; 3) melanggar surat keputusan bersama (SKB) nomor:106/PHDI-Bali/XII/2020 dan nomor: 07/SK/MDA-Prov Bali/XII/2020 tentang Kegiatan Pengemban Ajaran Sampradaya Non Dresta Bali di Bali.

PHDI Provinsi Bali dan Majelis Desa Adat (MDA) berpendapat bahwa Desa Adat memiliki kewenangan untuk melakukan tindakan/ mengeluarkan kebijakan yang terukur, termasuk melaksanakan penutupan ashram non Dresta Bali termasuk Ashram Krishna Balaram atau ISKCON (Winata, 2021). Aksi penutupan ashram di Desa Adat Kesiman ini diikuti penutupan ashram Radha Maha Candra Ashram di Desa Adat Alas Sangker Buleleng pada 28 April 2021.

Penutupan ashram Krishna Balaram oleh Desa Adat Kesiman ini mendapatkan perlawanan dari Lembaga Bantuan Hukum-Yayasan Lembaga Bantuan Hukum (YLBH) Bali yang menyatakan sikap bahwa tindakan penutupan ashram sebagai pelanggaran hukum,pelanggaran Hak Asasi Manusia (HAM) dan sikap intoleran terhadap hak atas kebebasan berkumpul dan berpendapat serta hak atas kebebasan beragama dan berkeyakinan untuk setiap warga negara 
Indonesia. YLBH juga menyampaikan beberapa tuntutan, yaitu: 1) SKB PHDI dan MDA dicabut; 2) Gubernur Bali melakukan upaya pencegahan terhadap tindakan intoleran terhadap kebebasan beragama dan berkeyakinan ; 3) Polisi hadir dalam melindungi masyarakat yang menjalani praktik agama dan kepercayaannya (Mustofa, 2021).

Dari fenomena dan dinamika sosial yang terjadi, hasil penelitian ini menunjukkan propaganda dan aksi dari Gema Hindu yaitu:1) bertujuan mendesak PHDI mencabut surat pengayoman untuk sampradaya Hare Krishna ISKCON, Saibaba dan sampradaya lainnya; 2) berhasil mendapat simpati secara luas dengan adanya dukungan Gubernur, DPRD, Majelis Desa Adat dan PHDI Provinsi Bali dan masyarakat Hindu secara nasional 3) menghasilkan Surat Keputusan Bersama (SKB) PHDI Provinsi Bali dan MDA Provinsi Bali; 4) menghasilkan tindakan penegakan hukum secara pre-emtif, preventif dan represif dalam pencegahan penistaan agama dan fundamentalisme serta radikalisasi agama di PHDI dan desa adat sebagai bagian dari partisipasi masyarakat dalam pertahanan negara.

\section{TEORI DAN METODE PENELITIAN}

Metode pengumpulan data dilakukan dengan observasi partisipatif, wawancara dan studi pustaka. Informan pada penelitian ini melibatkan beberapa tokoh gerakan sosial, seperti: 1) Tokoh Pergerakan dari Forum Komunikasi Taksu Bali yaitu: Putu Agus Yudiawan (pendiri Warih Mule Keto), Kismayana Wijanegara, I Made Dwiadnjanaadi Lokatanaya; 2) Ketua Umum Pusat Koordinasi Hindu (Puskor Hindunesia), Ida Bagus Susena; 3) Bendesa Agung Majelis Desa Adat Provinsi Bali, Ida Pangelingsir Agung Putra Sukahet; 4) Bendesa Adat Kesiman, Jro Mangku Wisna (JMW); 4) Koordinator Gerakan Kearifan Hindu Nusantara (GKHN), Komang Priambada, 5) Perguruan Tegal Mengkeb Tabanan, Maha Prabhu Pralagda Pandya: 6) Tim pengacara GKHN, I Ketut Seregig, dkk;7) Tim pengacara korban penganiayaan oleh AWK, Agung Sanjaya Dwijaksara,dkk; 8) Komponen Rakyat Bali, I Gusti Ketut Sumardayasa. Studi pustaka yang digunakan bersumber dari jurnal, e-book, tesis, artikel dan sumber teks lainnya, seperti UUD 1945, UU HAM, deklarasi PBB dan produk perudanganundangan serta peraturan kebijakan pemerintah lainnya.

Pendekatan teoritik yang digunakan dalam penelitian ini adalah teori gerakan sosial dan teori mobilisasi massa (mobilisasi popular). Gerakan sosial merupakan gerakan protes masalah sosial atau politik yang ditujukan untuk membuat publik dan politisi sadar akan adanya masalah sosial yang dilakukan dengan menyakinkan orang untuk bergabung dan berpartisipasi dalam menyelesaikan masalah. Berikut ini adalah penjelasan teori gerakan sosial dari Killian, dkk (Killian, 2020).

Gerakan sosial mencerminkan pengertian bahwa gerakan sosial secara intrinsik terkait dengan perubahan sosial. Gerakan sosial adalah kolektivitas atau usaha kolektif untuk mencapai tujuan bersama. Gerakan sosial memiliki tujuan menekankan transformasi pribadi, membawa perubahan sosial dengan mengubah mayoritas masyarakat untuk menerapkan nilai-nilai dengan tindakan mereka.

Gerakan sosial dapat dipengaruhi oleh faktor individu dan sosial. Faktor individu yang mempengaruhi gerakan sosial cenderung bersifat psikologi yang dari penderitaan yang meluas. Keterasingan politik, perasaan tidak berdaya, putus asa, dan keterasingan dari masyarakat dapat juga mempengaruhi individu untuk berpartisipasi. Keberadaan kemiskinan dan penderitaan yang meluas dapat menimbulkan upaya reformasi merupakan keadaan psikologis yang meyakinkan orang untuk bergabung dengan suatu gerakan atau melemahkan komitmen mereka pada kelompok konvensional. Mereka bersedia mengambil risiko karena keyakinan dan tujuan yang tidak populer.

Norma adalah ekspektasi standar dari perilaku yang dikembangkan oleh anggota. Nilai mencakup program dan ideologi. Program itu adalah skema perubahan, tatanan sosial baru yang diusulkan oleh gerakan itu. Ideologi adalah kumpulan ide yang membenarkan program dan strategi gerakan. Ini biasanya mencakup penafsiran ulang sejarah, proyeksi utopia yang akan diperkenalkan oleh keberhasilan gerakan, 
proyeksi konsekuensi bencana dari kegagalan, dan evaluasi ulang hubungan antara segmen populasi dan gerakan. Norma-norma ini mengatur perilaku yang akan melambangkan kesetiaan anggota terhadap gerakan sosial. Norma yang dimiliki adalah komitmen untuk melarang perilaku yang dapat mempermalukan gerakan atau memberikan alasan untuk serangan oleh lawan. Komitmen diperkuat dengan partisipasi dalam kegiatan kelompok dengan anggota lain dan dengan terlibat dalam tindakan, individu atau kolektif, yang secara publik mendefinisikan individu sebagai anggota yang berkomitmen.

Gerakan sosial tidak memiliki pemimpin yang sah dalam arti diberkahi otoritas melalui proses formal. Para pemimpin harus terusmenerus mendukung klaim kepemimpinan mereka dengan menunjukkan efektivitas pengaruh mereka terhadap para pengikut. Pemimpin bertangung jawab merumuskan kebijakan dan keputusan yang akan menghasilkan tanggapan pengikutnya. Pemimpin tidak memiliki otoritas dalam arti kekuasaan yang dilegitimasi, dan anggota tidak dilantik secara formal. Prosedur pengambilan keputusan formal menempatkan premi pada keyakinan dan loyalitas di pihak anggota komitmen terhadap gerakan dan nilai-nilainya menjadi salah satu sumber kendali terpenting.

Strategi dan perubahan strategi sangat dipengaruhi oleh hubungan gerakan sosial dengan masyarakat luas dan gerakan sosial lainnya. Strategi yang digunakan adalah dengan memanipulasi melalui persuasi, non kekerasan hingga menggunakan taktik kekerasan. Strategi Gerakan sosial beragam bentuk seperti: reformasi, revolusi, kekerasan, non-kekerasan.

Gerakan sosial reformasi menganjurkan perubahan yang akan melestarikan nilai-nilai yang ada tetapi memberikan cara yang lebih baik untuk menerapkannya. Gerakan revolusioner menganjurkan penggantian nilainilai yang ada. Sebuah gerakan yang cenderung dilakukan dengan kekerasan, mengancam nilainilai kelompok kepentingan yang kuat dan signifikan dalam masyarakat. Gerakan nonkekerasan juga dapat didefinisikan sebagai revolusioner atau radikal ketika lebih memilih melakukan pembangkangan sipil, daripada manuver hukum atau parlementer.

Propaganda menjadi alat kepemimpinan yang penting untuk mendapatkan dukungan. Propaganda juga penting untuk menjaga moral dan persatuan. Pidato dan tulisan para pemimpin berfungsi, sebagian, untuk meyakinkan para pengikut tentang ukuran, kekuatan, dan potensi keberhasilan gerakan. Gerakan memang memanfaatkan hubungan antarpribadi untuk meningkatkan persatuan mereka, mendorong kelompok kecil anggota untuk sering bertemu membentuk ikatan pribadi. Pertemuan massal dan parade, dengan ritual yang menyertainya, mengurangi perasaan terisolasi yang mungkin dialami oleh anggota yang terpencar-pencar.

Teori yang lebih umum tentang asal mula gerakan sosial, seperti Smelser, Turner, dan Killian, menunjukkan bahwa perubahan sosial dapat mengakibatkan ketegangan atau konflik dalam satu atau lebih aspek penting dari tatanan sosial. Ketegangan normatif muncul ketika kondisi yang berubah menciptakan situasi di mana norma-norma yang ditetapkan tidak lagi mengarah pada pencapaian nilai-nilai penting yang diterima. Ketegangan dalam nilai-nilai muncul ketika nilai-nilai itu sendiri tampaknya mengganggu pemenuhan kebutuhan penting suatu segmen masyarakat. Ketegangan semacam ini sering muncul ketika kelompokkelompok yang berbeda, seperti pendatang, minoritas, atau generasi muda, mengembangkan nilai-nilai yang bertentangan dengan nilai-nilai kelompok yang lebih mapan.

\section{PEMBAHASAN}

\section{a. Gerakan Masyarakat Hindu (Gema Hindu)}

Gema Hindu menolak ideologi dan organisasi transnasional sampradaya di PHDI pada awalnya digerakkan kelompok massa yang didukung oleh Forum Komunikasi Taksu Bali dan Taksu Bali Dwipa, Pusat Koordinasi Hindunesia (Puskor Hindunesia), Gerakan Kearifan Hindu Nusantara (GKHN), Komponen Rakyat Bali (KRB), Amukti Palapa Nusantara (APN), YJHN, Cakra Wahyu, Brahmastra, sejumlah sulinggih (pinandita), warga Nusa Penida dan relawan pemerhati Hindu nasional 
lainnya. Gema Hindu bergerak sebagai respon atas sejumlah penistaan simbol agama Hindu dengan identitas aksi solidaritas:1) "Bali Metangi", 2) "Bali Masadu" 3) "Bali Magejeran" dan 4) "Bali Deklarasi".

Bali Metangi dengan koordinator Putu Agus Yudiawan melakukan aksi pada 3 Agustus 2020 di lapangan Bajra Sandhi Renon menuntut PHDI mengeluarkan Hare Krishna/ISKCON dari PHDI karena meresahkan dan penegakan hukum sesuai dengan SK Kejaksaan Agung tentang pelarangan peredaran buku dan ajaran Hare Krishna (Mustofa, 2020). Bali Mesadu melakukan aksi yang dipimpin Ketua Umum Forum Komunikasi Taksu Bali Dwipa, Tjok Bagus Oka di Gedung DPRD dan mendapatkan rekomendasi langsung dari DPRD untuk Gubernur Bali segera mengambil sikap pembubaran Hare Krishna (Bali, 2020). Rekomendasi merupakan hasil dari Rapat Pimpinan (Rapim) DPRD Bali yang dituangkan dalam Surat DPRD Bali Nomor: 030/4260/ DPRD Bali dan telah dikirimkan kepada Gubernur Bali, Wayan Koster (Bali P. , 2020).

Bali Magejeran merupakan aksi yang diadakan pada 3 November 2020 di Depan Monumen Puputan Klungkung diterima Bupati Klungkung, I Nyoman Suwirta yang mengecam sikap AWK yang melakukan penistaan terhadap simbol keagamaan di Nusa Penida (Klungkung, 2020). Kordinator aksi dari Nusa Penida dipimpin oleh I Wayan Sukla (Bali T. , 2020). Aksi menuntut Arya Weda Karna sebagai anggota DPD RI untuk dilengserkan dari jabatannya dan Hare Krishna dikeluarkan dari PHDI (Rahmayunita, 2020). Hal ini dipicu beredarnya sejumlah video milik Arya Weda Karna (AWK) yang juga dikenal sebagai bhakta Hare Krishna ini atas tindakannya menghina adat istiadat keagamaan Hindu di Nusa Penida dan Bali.

Dalam berbagai video miliknya, AWK dianggap telah merendahkan dewa-dewa di tempat pemujaan, termasuk di Pura Dalem Peed Nusa Penida dengan sebutan mahluk. AWK juga mendoakan para sulinggih atau ulama di Bali berumur pendek dalam berbagai ceramahnya yang bukan menjadi tugas pokok dan fungsinya sebagai DPD. Akibat dari tindakan ini AWK dilaporkan ke Polda Bali dan Badan Kehormatan
DPD RI. AWK dianggap sebagai representasi dari perilaku dari bhakta dan praktik dari ajaran Hare Krishna yang dianggap sesat.

Tindakan pelecehan yang dilakukan AWK terhadap simbol agama Hindu yang disucikan warga Pulau Nusa Penida ini disebarkan secara meluas oleh netizen di media sosial sehingga memicu protes kemarahan demonstran pihak Sandhi Murti yang dipimpin korlap. I Gusti Ngurah Komang Juniarta dan melakukan pemukulan terhadap AWK di halaman Gedung DPD RI di Renon pada 28 Oktober 2020 (Balinetizen, 2020). Aksi ini menimbulkan dampak hukum dimana kedua belah pihak saling lapor ke Polda Bali.

Majelis Desa Adat (MDA) juga telah mengidentifikasi adanya tokoh-tokoh sampradayayangsangatseringmendeskreditkan adat istiadat bali dan desa adat di Bali seperti mencela, memanipulasi ajaran Hindu Bali dan Hindu Nusantara dan menyebarluaskannya, serta bertujuan untuk mengganti adat istiadat Bali, budaya Bali dan desa adat Bali dengan tata cara keagamaan, adat dan budaya asing (BBN, 2021).

Dampak dari sikap arogansi AWK menantang masyarakat ini menjadikan gerakan sosial ini berkembang menjadi penolakan terhadap Hare Krishna/ISKCON dan sampradaya lain. Gema Bali memperluas orientasi tuntutan dengan mendesak Hare Krishna dan sampradaya lain untuk keluar dari pengayoman PHDI. Gerakan ini juga menuntut reformasi AD/ART beserta kepengurusan PHDI yang dianggap melakukan kekeliruan dalam memberikan pengayoman terhadap ideologi dan organisasi transnasional Hare Krishna (ISKCON), Sai Baba dan sampradaya lainnya. Faktanya menunjukkan pernyataan pendiri dan organisasi sampradaya tidak mengakui dan tidak melaksanakan ajaran Hindu sesuai pakem di Indonesia yang berbasis pada kearifan lokal.

Gubernur Bali mendukung Keputusan Bersama Parisada Hindu Dharma Indonesia Provinsi Bali dan Majelis Desa Adat Provinsi Bali Nomor : 106/PHDI-Bali/XII/2020, Nomor: 07/ SK/MDA-Prov Bali/XII/2020 Tentang Pembatasan Kegiatan Pengembanan Ajaran Sampradaya Non-Dresta Bali di Bali (Mustofa, 2020). Gerakan sosial ini berkembang, menguat 
dan kemudian mendapat dukungan luas dari Majelis Desa Adat dan desa adat se-Bali, DPRD Provinsi Bali dan Gubernur Bali, Bupati Klungkung, PHDI Provinsi Bali, masyarakat pemerhati Hindu di Indonesia termasuk Prajaniti Banten.

Dalam zoominar yang diselenggarakan GKHN pada 25 April 2021, tokoh PHDI Sulawesi Utara, Ida Bagus Alit pengurus PHDI Sulawesi Utara menyatakan perkiraan 63\% Pengurus PHDI seIndonesia memberikan suara dukungan terhadap Gerakan Masyarakat Hindu untuk mereformasi dan membuat perubahan AD/ART di PHDI Pusat. Gema Hindu sebagai gerakan sosial melakukan mobilisasi dengan cara-cara bersemuka melalui aksi protes damai dengan mengajukan tuntutan yang disertai dengan pertunjukan seni budaya. Saluran jejaring di media sosial melakukan menggunakan kanal facebook melalui beberapa akun seperti: Nanang Kelor, Nimade Padmi, I Cening Sutiadnya, Suara Bali, Taksu Bali, dan akun lain milik simpatisan pergerakan yang bersifat perorangan. Media sosial yang digunakan selain facebook juga whatsapp, instagram, telegram dll.

Propaganda atau pesan politik yang disampaikan Gema Hindu ini memuat beberapa pokok pikiran :1) menuntut penegakan hukum terhadap penistaan simbol agama Hindu yang dilakukan pejabat DPD RI yaitu oleh AWK; 2) menuntut PHDI mencabut pengayoman Hare Krishna,Sai Baba dan sampradaya lain; 3) mereformasi PHDI dengan menghapus pasal pengayoman sampradaya di PHDI; 4) menutup ashram Hare Krishna dan sampradaya di seluruh Bali; 5) Menegakkan dresta (adat istiadat dan agama) sesuai dengan keberadaannya di desa adat masing-masing. Dasar hukum kerangka bertindak yang dijadikan acuan oleh Gema Hindu untuk menolak pengayoman ideologi dan organisasi sampradaya di PHDI dan di desa adat sekaligus menjawab tudingan dari kelompok sampradaya dan YLBH yang menyatakan Gema Hindu intoleran dan melanggar HAM sebagai berikut.

\section{Deklarasi PBB tentang Hak-Hak Penduduk Asli}

a. Deklarasi PBB tentang Hak-Hak Penduduk Asli adalah sebuah deklarasi yang disahkan Majelis Umum Perserikatan Bangsa-Bangsa (MU PBB) dalam sesi ke-61-nya di Markas PBB di New York, 13 September 2007. Deklarasi ini mengatur hak terhadap budaya, identitas, bahasa, pekerjaan, kesehatan, pendidikan dan isu-isu lainnya. Deklarasi ini melarang diskriminasi terhadap penduduk asli, dan mendorong untuk memajukan partisipasi penduduk asli secara penuh dan efektif dalam segala hal yang menyangkut massalah mereka, serta hak untuk tetap berbeda, dan mengusahakan visi pembangunan ekonomi dan sosial mereka sendiri. Adapun pasal yang mengatur hak masyarakat adat dalam deklarasi ini sebagai berikut:

b. Pasal 8 : Masyarakat adat dan warga negaranya memiliki hak untuk tidak menjadi target dari pemaksaaan pencampuran budaya dan pengrusakan budaya mereka. Negara akan menyediakan mekanisme yang efektif untuk mencegah dan mengganti kerugian atas: Setiap tindakan yang mempunyai tujuan atau berakibat pada hilangnya keutuhan mereka sebagai kelompok masyarakat yang berbeda atau dari nilainilai kultural atau identitas etnik mereka.

c. Pasal 11: Masyarakat adat mempunyai hak untuk mempraktikkan dan memperbarui tradisi-tradisi dan adat budaya mereka. Hal ini meliputi hak untuk mempertahankan, melindungi, dan mengembangkan wujud kebudayaan mereka di masa lalu, sekarang dan yang akan datang seperti situs-situs arkeologi dan sejarah, artefak, disain, upacaraupacara, teknologi, seni visual dan seni pertunjukan dan kesusasteraan. Negaranegara akan melakukan pemulihan melalui mekanisme yang efektif termasuk restitusi, yang dibangun dalam hubungannya dengan masyarakat adat, dengan rasa hormat pada kekayaan budaya, intelektual, religi dan spiritual mereka yang telah diambil tanpa persetujuan bebas dan sadar dari mereka, atau yang melanggar hukum- 
hukum tradisi dan adat mereka.

d. Pasal 12: masyarakat adat mempunyai hak untuk mewujudkan, mempraktikkan, mengembangkan dan mengajarkan tradisi, kebiasaan, dan upacara spiritual dan religi mereka; hak untuk mempertahankan, melindungi dan mempuyai akses dengan keleluasaan pribadi terhadap situs-situs religi dan kultural mereka; hak akan penggunaan dan kontrol terhadap objek-objek seremonial mereka; dan hak akan repatriasi jasad manusia mereka.

e. Pasal 31 : Masyarakat adat memiliki hak untuk menjaga, mengontrol, melindungi dan mengembangkan, warisan budaya mereka, pengetahuan tradisional dan ekspresi-ekspresi budaya tradisional, seperti juga manifestasi ilmu pengetahuan mereka, teknologiteknologi dan budaya-budaya, termasuk sumber daya manusia dan sumber daya genetik lainnya, benih- benih, obatobatan, permainan-permainan tradisional dan seni pentas. Mereka juga memiliki hakuntuk menjaga, mengontrol, melindungi dan mengembangkan kekayaan intelektual, warisan budaya, pengetahuan tradisional, dan ekspresiekspresi budaya mereka.

\section{Konstitusi UUD 1945}

a. Pasal 18 B ayat 2 berbunyi: Negara mengakui dan menghormati kesatuankesatuan masyarakat hukum adat serta hak-hak tradisonalnya sepanjang masih hidup dan sesuai dengan perkembangan masyarakat dan prinsip Negara Kesatuan Republik Indonesia, yang diatur dalam undang-undang.

b. Pasal 28 E: setiap orang bebas memeluk agama dan beribadat menurut agamanya, memilih Pendidikan dan pengajaran, memilih pekerjaan, memilih kewarganegaraan, memilih tempat tinggal di wilayah negara dan meninggalkannya serta berhak untuk kembali.

c. Pasal 28 J yang berbunyi ayat (1) berbunyi: Setiap orang wajib menghormati HAM orang lain; ayat (2) Dalam menjalankan hak dan kebebasannya setiap orang tunduk kepada pembatasan-pembatasan yang ditetapkan dengan undang-undang dengan maksud semata-mata untuk menjamin pengakuan serta penghormatan atas hak dan kebebasan orang lain dan untuk memenuhi tuntutan yang adil sesuai dengan pertimbangan moral, nilai-nilai agama,keamanan dan ketertiban umum dalam suatu masyarakat demokratis sesuai pertimbangan moral, nilai-nilai agama, keamanan, dan ketertiban umum.

d. Pasal 29 ayat 2 yang berbunyi : Negara menjamin kemerdekaan bagi setiap penduduk untuk memeluk agamanya masing-masing dan untuk beribadat menurut agamanya dan kepercayaannya.

e. Pasal 30 ayat 1 : tiap-tiap warga negara berhak dan wajib ikut dalam usaha pertahanan dan keamanan negara.

3. UU No 39/1999 Tentang HAM pada pasal 73 berbunyi : Hak dan kebebasan yang diatur dalam Undang- Undang ini hanya dapat dibatasi oleh dan berdasarkan undang-undang sematamata untuk menjamin pengakuan dan penghormatan terhadap hak asasi manusia, serta kebebasan dasar orang lain, kesusilaan, ketertiban umum, dan kepentingan bangsa.

4. UU No 4/PNPS/1963 tentang Pengamanan Terhadap Barang Cetakan yang isinya dapat mengganggu ketertiban.

5. UU PNPS No 1 Tahun 1965 tentang Penetapan Presiden Republik Indonesia tentang Pencegahan Penyalahgunaan dan/Atau penodaan Agama. Dalam UU PNPS No 1 tahun 1965 beberapa pasal yang dirujuk sebagai berikut.

a. Pada pasal 1 berbunyi: Setiap orang dilarang dengan sengaja di muka umum menceritakan,menganjurkan atau mengusahakan dukungan umum, untuk melakukan penafsiran tentang sesuatu agama yang dianut di Indonesia atau melakukan kegiatan -kegiatan keagamaan yang menyerupai kegiatan 
keagamaan yang menyerupai kegiatankegiatan keagamaan itu, penafsiran dan kegiatan mana menyimpang dari pokok agama itu.

b. Pasal 2 ayat 1 berbunyi: Barang siapa melanggar ketentuan tersebut dalam pasal 1 diberi perintah dan peringatan keras untuk menghentikan perbuatannya itu di dalam suatu keputusan bersama Menteri Agama, Menteri/Jaksa Agung dan Menteri dalam negeri.

c. Pasal 2 ayat 2 berbunyi : Apabila pelanggaran tersebut dalam ayat (1) dilakukan oleh organisasi atau sesuatu aliran kepercayaan, maka Presiden Republik Indonesia dapat membubarkan organisasi itu dan menyatakan organisasi atau aliran tersebut sebagai Organisasi/ Aliran terlarang, satu dan lain setelah mendapat pertimbangan dari Menteri Agama, Menteri/Jaksa Agung dan Menteri Dalam Negeri.

d. Pasal 4 berbunyi: Pada Kitab UndangUndang Hukum Pidana diadakan pasal baru yang berbunyi sebagai berikut: Pasal 156a berbunyi: Dipidana dengan pidana penjara selama-lamanya lima tahun barang siapa dengan sengaja di muka umum mengeluarkan perasaan atau melakukan perbuatan: a) yang bersifat permusuhan, penyalahgunaan atau penodaan terhadap suatu agama yang dianut di Indonesia;b) dengan maksud agar supaya orang tidak menganut apapun juga yang bersendikan Ketuhanan yang Maha Esa.

Pasal 156a KUHP merupakan delik penodaan agama atau penistaan agama. UU No 1 PNPS/1965 membatasi perlindungan hukum terhadap agama dari penyimpangan dan penodaan terhadap agama yang dilindungi yaitu: Islam, Kristen, Katolik,Hindu, Budha dan Kong $\mathrm{Hu} \mathrm{Cu}$. Sedangkan aliran kepercayaan mendapat perlindungan menurut pasal 29 ayat (2) UUD 1945 (Christianto, 2013).

6. UU Nomor 6 tahun 2014 tentang Desa pasal 1 berbunyi: Desa adalah desa dan desa adat yang disebut dengan nama lain, selanjutnya disebut Desa, adalah kesatuan masyarakat hukum yang memiliki batas wilayah yang berwenang untuk mengatur dan mengurus urusan pemerintahan, kepentingan masyarakat berdasarkan prakarsa masyarakat, hak asalusul, dan/atau hak tradisional yang diakui dan dihormati dalam sistem pemerintahan Negara Kesatuan Republik Indonesia

\section{Perda Provinsi Bali Nomor 4 tahun} 2019 tentang Desa Adat di Bali, yaitu:

a. Pasal 21 berbunyi: Desa adat memiliki tugas mewujudkan kesukertan desa Adat yang meliputi ketenteraman, kesejahteraan,kebahagiaan, dan kedamaian sekala dan niskala.

b. Pasal 22 hurup (d) berbunyi: memajukan adat, agama,tradisi, seni dan budaya serta kearifan lokal masyakat desa adat

c. Pasal 22 hurup (n) berbunyi: melaksanakan kegiatan lain sesuai dengan awig-awig dan/atau dresta.

d. Pasal 23 berbunyi : kewenangan desa adat meliputi kewenangan berdasarkan hak asal-usul dan kewenangan lokal berskala desa adat.

8. Perda Provinsi Bali nomor 4 tahun 2020 tentang Penguatan Dan Pemajuan Kebudayaan Bali.

a. Pasal 1 nomor 8 berbunyi: Desa adat adalah kesatuan masyarakat hukum adat di Bali yang memiliki wilayah, kedudukan,susunan asli,hak-hak tradisional, harta kekayaan sendiri, tradisi,tata krama pergaulan hidup, masyarakat secara turun temurun dalm ikatan tempat suci (kahyangan tiga atau kahyangan desa), tugas dan kewenangan serta hak mengatur dan mengurus rumah tangganya sendiri.

b. Pasal 7 ayat (1) berbunyi: objek penguatan dan pemajuan budaya meliputi :a) kearifan lokal; b)ritus; c) benda sakral;d) pengetahuan tradisional; e) teknologi tradisional;f) pengobatan tradisional;g) tradisi lisan; $\mathrm{h}$ ) manuskrip;.i) situs; j) adat istiadat;k) seni;l) arsitektur tradisional; m) bahasa 
dan aksara; n) permainan rakyat.

\section{Surat Keputusan Kejaksaan Agung RI Nomor :Kep-107/J.A/5/1984}

Dalam penanganan polemik Hare Krishna, PHDI melakukan audiensi dengan tim Pakem kejaksaan Tinggi Bali mengenai Surat Keputusan KejaksaanAgungRINomor:Kep-107/J.A/5/1984 tentang Larangan Peredaran Barang-Barang Cetakan Yang Memuat Ajaran Kepercayaan Hare Krsna di Seluruh Indonesia. Hasil audiensi menunjukkan bahwa kedudukan SK Kejaksaan Agung tersebut masih berlaku, namun tidak dapat diterapkan (Artaya, 2020).

Berdasarkan hasil kajian dari I Ketut Seregig dalam zoominar yang diselenggarakan GKHN 25 April 2021 dinyatakan bahwa SK Kejaksaan Agung RI Nomor:Kep-107/J.A/5/1984 masih berlaku dan tentu saja dapat diterapkan, hanya saja pada mekanisme terjadi perubahan yang sebelumnya kejaksaan dapat melakukan penyitaan, namun kini pelaksanaannya harus dilakukan melalui Lembaga Peradilan. Ini artinya fungsi pengawasan dan penyidikan dapat dilakukan kejaksaan selama ada pengaduan dari masyarakat dan dilanjutkan perkaranya ke lembaga peradilan.

Gerakan Masyarakat Hindu Menolak Pengayoman Ideologi dan Organisasi Transnasional Sampradaya di PHDI merupakan gerakan sosial yang ditujukan untuk mereformasi kebijakan PHDI Pusat untuk mencabut pengayoman terhadap Hare Krishna/ ISKCON dan seluruh sampradaya di PHDI. Gema Hindu bergerak secara internal di Bali melalui jalur pengerahan massa dimotori oleh Forkom Taksu Bali. Secara eksternal, Gerakan Kearifan Hindu se-Nusantara (GKHN) menjadi penyambung komunikasi Gema Hindu di Bali dengan Gerakan masyarakat pemerhati Hindu Indonesia termasuk PHDI se-Indonesia.

Kepemimpinan dalam Gema Hindu disebut dengan koordinator yang dipilih berdasarkan karisma, karakter dan komitmen terhadap perjuangan dan kelompok. Keputusan dalam pergerakan dibuat berdasarkan keputusan kolektif kolegial. Mobilisasi yang dilakukan Gema Hindu dalam melakukan penolakan terhadap pengayoman ideologi dan organisasi transnasional ini dilakukan dengan bersemuka, mobilisasi massa dan juga menggunakan media sosial. Kekuatan media sosial dipergunakan kelompok untuk mengarahkan masyarakat sesuai dengan agenda (Dwiana, 2013).

Penggunaan media sosial dirasakan efisien dan bermanfaat dalam gerakan masyarakat ini. Pertama, masyarakat pendukung mematuhi diberlakukannya protokol kesehatan oleh pemerintah pada masa pandemi Covid 19 yang membatasi orang untuk berkumpul dan mengurangi resiko pelanggaran hukum jika melibatkan massa di lapangan. Kedua, video dan gambar yang dibagikan secara online juga dapat menjangkau massa lebih luas dengan citra yang lebih dramatis. Ketiga, penggunaan media sosial dapat mempengaruhi sikap netizen karena dapat memperoleh gambaran tentang realitas yang dicitrakan lebih jujur.

Dampak dari Gerakan Masyarakat Hindu terhadap Penolakan Pengayoman Ideologi dan Organisasi Sampradaya di PHDI menghasilkan beberapa regulasi dan beberapa tindakan seperti pre-emtif, preventif dan represif yang didukung Majelis Desa Adat, PHDI, Gubernur dan DPRD Provinsi Bali. Dampak Gerakan Masyarakat Hindu ini dapat disampaikan sebagai berikut.

\section{Rekomendasi PHDI Bali}

PHDI Provinsi Bali menetapkan rekomendasi usulan pencabutan pengayoman PHDI per tahun 2016 terhadap Hare Krishna ISCKON yang tertuang dalam Keputusan Parisada Hindu Dharma Indonesia Provinsi Bali nomor: 066/ PHDI-Bali/VIII/2020 tentang Menyikapi Massalah Sampradaya Hare Krishna/ISCKON pada tanggal 1 Agustus 2020. Dalam surat ini pula PHDI Bali melarang Sampradaya Hare Krishnamenggunakan pura dan wewidangannya, tempat-tempat umum/fasilitas publik seperti lapangan, jalan, pantai dan lain-lain untuk melakukan kegiatan Hare Krishna ISKCON. Usulan ini diberikan karena Hare Krishna ISCKON telah dianggap melakukan pelanggaran terhadap kesepakatan bersama tahun 2001.

\section{Surat Keputusan Bersama PHDI Provinsi Bali dan MDA Provinsi Bali}

Gerakan Masyarakat Hindu berhasil menyatukan komitmen PHDI dan MDA Provinsi 
Bali dalam menangani polemik Hare Krishna dan sampradaya lain dengan terbitnya Surat Keputusan Bersama (SKB) nomor: 106/PHDIBali/XII/2020, Nomor 07/SK/MDA-Prov Bali/ XII/2020 tentang Pembatasan Kegiatan Pengembanan Ajaran Sampradaya Non-Dresta Bali di Bali. SKB ini didukung Gubernur Bali (Dewata, 2020).

\section{Tindakan Pre-emtif}

Gerakan Masyarakat Hindu melakukan kegiatan pre-emtif dan edukatif dengan cara membuka dialog terbuka dalam bentuk zoominar yang dilakukan Gerakan Kearifan Hindu se-Nusantara di Jakarta membahas tentang: orientasi gerakan, kajian terhadap regulasi, dan diskusi tentang sumber-sumber yang potensial menimbulkan kegaduhan dan stabilitas negara berkaitan dengan eksitensi Hare Krishna dan sampradaya lainnya. Hasil dari pembahasan disiarkan secara langsung (live streaming) di facebook sehingga dapat diikuti masyarakat secara luas. Gerakan Masyarakat Hindu di Bali melalui saluran forum komunikasi dan komunitas juga melakukan diseminasi terkait dengan regulasi PHDI dan MDA kepada desa adat dan masyarakat adat Hindu di Bali. Gerakan Masyarakat Hindu ini membangun kesadaran masyarakat luas bahwa gerakan sosial ini juga ditujukan untuk memperjuangkan eksistensi dan hak umat Hindu Nusantara di Indonesia.

\section{Tindakan Preventif}

Gerakan Masyarakat Hindu melakukan tindakan preventif membendung ideologi dan organisasi transnasional sampradaya dalam bentuk deklarasi penolakan sampradaya dan pemasangan spanduk sosialisasi SKB PHDI dan MDA tentang pembatasan aktivitas pengemban sampradaya di desa-desa adat. Selain itu aktivitas lain adalah mengumpulkan buku-buku ajaran Hare Krishna yang diperoleh dari masyarakat yang suka rela menyerahkan buku tersebut untuk menegakkan SK Kejaksaan Agung RI nomor 107/J.A/5/1984 tentang larangan peredaran barang-barang cetakan yang memuat ajaran Hare Krsna di seluruh Indonesia dan digunakan sebagai barang bukti pelaporan.

\section{Tindakan Represif Penutupan Ashram Sampradaya Non-Dresta Bali}

Penutupan Ashram Krishna Balaram di Padang Galak oleh Desa Adat Kesiman pada 18 April 2021. Penutupan ashram lain juga diikuti oleh Desa Adat di wewidangan (batas wilayah adat) masing-masing. Radha Maha Candra Ashram ditutup Desa Adat Alas Sangker pada 28 April 2021. Prosedur penutupan ashram dilakukan dengan cara-cara damai, profesional dan sesuai prosedur yang diawali dengan pembacaan SKB PHDI dan MDA oleh bendesa adat, disaksikan oleh pecalang dan pihak kepolisian. Hasil penutupan ini dilaporkan kepada MDA, Gubernur sehingga tindakan ini tidak dapat dikatakan sebagai pelanggaran HAM.

Ketua DPRD Provinsi Bali, Nyoman Adi Wiryatama mendukung aksi penutupan ashram di Padang Galak (Mds, 2021). Gubernur Bali, I Wayan Koster memberikan dukungan dengan melarang Bendesa ikut sampradaya dan meminta Bendesa yang terpapar sampradaya untuk berhenti menjadi bendesa dan mengingatkan para prajuru adat dan krama adat untuk tetap menjaga desa adat agar tidak terpapar (NV, 2020) .

\section{b. Sampradaya}

Sampradaya merupakan kata kerja yang berarti memberi, menghadiahi menyerahkan, menganugrahkan, menurunkan melalui tradisi mewariskan sebuah philosofi melalui parampara atau garis keturunan yang hidup dari para guru yang telah disucikan serta mengejawantahkan dan meneruskan sampradaya melalui inisiasi (Haryani, 2016).

Bendesa Agung Majelis Desa Adat, Ida Penglingsir Agung Putra Sukahet menyatakan sampradaya non-dresta Bali merupakan organisasi dan/atau perkumpulan yang mengemban paham, ajaran dan praktek ritual yang tata pelaksanaannya tidak sesuai dengan adat, tradisi, seni dan budaya serta kearifan lokal dresta Bali (Devita, 2020)

Kiprah sampradaya tidak dapat dilepaskan dari peran representatif guru-guru spiritual atau rohaniawan dari luar negeri. Selain Hare Krishna ISCKON, Sai Baba dan Sikh juga terdapat 
guru-guru spiritual dan murid-murid perguruan yang berkewarganegaran asing datang di berbagai ashram seperti: ashram Raja Yoga (Dr. Somvir, asal India); Brahma Kumaris (Sister Janaki, asal Malaysia); 3) Ashram Gandhi Puri (Abhisek Jagadish, asal India), Ashram Ratu Bagus (Ratu Bagus); ashram Paramadhama (Prabhu Dharmayasa dan Dr. Lidya dari Malta); 6) Sai Baba Study Club (Abimayu Kaul dari Kanada Keturunan India) (Haryani, 2016).

Fenomena ideologi dan organisasi sampradaya dan masuknya guru-guru kerohanian dari luar negeri terjadi karena dampak dari globalisasi yang mengakibatkan terjadinya perubahan sosial, pergerakan manusia menjadikan batas wilayah sosial dan budaya menjadi kabur.Pergeseran kehidupan masyarakat agraris menjadi masyarakat industri terutama industri pariwisata menjadi faktor masuknya ideologi dan organisasi sampradaya yang memberikan alternatif melakukan praktik keagamaan yang lebih praktis, mudah, murah dan menjadi jalan keluar dari tekanan adat istiadat.

Penganut ideologi dan organisasi sampradaya melalui gerakan para misionarinya menggunakan propaganda bahwa ritual keagamaan Hindu tradisional/ Hindu nusantara sebagai praktik ritual berbiaya tinggi atau mahal, membuang waktu karena ritual yang sangat panjang dan tidak berbasis pada kitab suci veda. Propaganda ini menjadi paradoks dengan kenyataan industri pariwisata Bali justru bergantung dari produk pariwisata berbasis pada budaya Bali. Demikian pula dalam penyelenggaraan ritual terdapat pilihan-pilihan rasional yang tersedia dari yang paling sederhana dan murah (nista), standar (madya) hingga istimewa, mewah dan mahal (uttama).

Pengikut ideologi dan organisasi sampradaya di Indonesia juga mencari dan menggunakan konteks lokal dengan menggunakan wacana kebhinnekaan, Ketuhanan Yang Maha Esa dan intoleransi. "Bhinneka Tunggal Ika, Tan Hana Dharma Mangrwa" karya empu Tantular yang menjadi sesanti bangsa lahir dari perjanjian penghormatan terhadap budaya-budaya nusantara milik masyarakat Indonesia. Wacana kebhinekaan yang digunakan sampradaya tidak tepat dalam konteks ke-Indonesia-an. Faktanya ideologi dan organisasi transnasional mengembangkan identitas budaya (diaspora) dari negara asal agama yang dianut sampradaya. ISKCON mengembangkan budaya abad pertengahan atau abad ke-15, cara dan gaya hidup masyarakat Benggala (setelah pemisahan, Benggala timur disebut Banglades, Benggala barat masuk wilayah India).

Diaspora budaya Benggala abad pertengahan ini dianggap sebagai sebagai tonggak peradaban dan budaya veda yang puritan (murni). Diaspora Benggala ini diadopsi oleh orang-orang Bali dan Indonesia yang tidak memiliki afiliasi atau sejarah kelahiran atau menjadi warga negara India atau Banglades. Berbeda halnya dengan sampradaya Agama Sikh yang memang mewariskan budaya dari nenek moyangnya dari India yang bermigrasi menjadi imigran dan kemudian menjadi penduduk Indonesia.

Wacana Ketuhanan yang Maha Esa yang sering digunakan penganut sampradaya tidak sesuai dengan konteks Indonesia mengingat Tuhan menurut Hindu di Indonesia bukan merupakan pengkultusan manusia. Demikian pula wacana intoleransi yang ditudingkan kepada Gema Hindu menjadi tidak tepat. Gema Hindu merupakan gerakan sosial yang dilakukan sebagai partisipasi masyarakat terhadap ideologi dan organisasi transnasional (ideologi asing) dan pencegahan fundamentalisme dan radikalisasi agama dan kepercayaan yang dapat merongrong NKRI dan Pancasila.

Pengikut ideologi dan organisasi sampradaya berargumentasi bahwa memiliki Tuhan dengan nama yang berbeda adalah kebebasan. Padahal konteks Ketuhanan yang Maha Esa di Indonesia haruslah mengacu pada ketuhanan sesuai dengan agama masing-masing yang diakui di Indonesia. Agama Hindu di Indonesia menyebut Tuhan dengan Ida Sang Hyang Widi Wasa dengan pakem keagamaan yang telah ditetapkan sesuai dengan kearifan budaya nusantara. Sebagian pengikut sampradaya ada yang menyebut dirinya sebagai sampradaya dresta Bali dengan dalih melaksanakan agama sampradaya dan agama Hindu adat Bali sekaligus. Ini artinya, para pengikut sampradaya telah menistakan agama dengan menduakan Tuhan. Padahal dalam praktiknya di Indonesia, tidak ada umat agama manapun di Indonesia 
yang dibenarkan menduakan Allah, Kristus, Budha dan juga Ida Sang Hyang Widhi.

c.Ideologi dan Organisasi Transnasional

Ideologi transnasional dipahami sebagai gerakan politik internasional yang berusaha mengubah tatanan dunia berdasarkan ideologi keagamaan fundamentalistik, tekstual, skriptualis radikal, sangat puritan dan bersikap ekslusif (Aksa, 2017), melakukan klaim sepihak atas nama agama atau Tuhan (Muhammad, 2020). Aturan keagamaan bersifat tunggal sesuai tafsir mereka sendiri, aturan manusia dianggap menyingkirkan kekuasaan Tuhan. Dengan demikian, ideologi ini menentang konsep negara-bangsa (nation-state) yaitu tentang negara modern yang terkait erat dengan paham kebangsaan dan nasionalisme. Gerakan puritan serta fundamental merupakan kelompok yang secara konsisten dan sistematis menganut absolutisme, berpikir dikotomis dan idealistik yang menolak kompromi dan toleran terhadap realitas pluralistik (Adiwilaga, 2017)

Ideologi transnasional merupakan paham atau pemikiran yang disebarkan secara lintas batas negara bersama identitas yang mewakilinya. Ideologi Transnasional dipersepsikan dalam bentuk neoliberalisme dan fundamentalisme agama yang merupakan ancaman terhadap negara, Pancasila dan nilai kearifan lokal (Padipto Bhagaskoro, 2019).

Romo Magnis Suseno menyatakan ideologi transnasional yang menggunakan kendaraan agama dan bertentangan dengan ideologi Pancasila dapat mensubversikan bangsa Indonesia dan dapat mengancam stabilitas dan keutuhan NKRI dan disusupkan melalui sekolahsekolah berbahaya sehingga perlu untuk diberangus (BW, 2017).

Dalam politik kebangsaan di Indonesia, ideologi transnasional menjadi ancaman bagi keutuhan NKRI karena tujuan untuk menerapkan hukum-hukum agama secara formal atau sekaligus pendirian negara berdasarkan keyakinan keagamaan tertentu di tengah-tengah kewarganegaran yang plural. Modus yang dilakukan organisasi transnasional yaitu mengibarkan simbol-simbol agama dan mengutip kalimat suci ketuhanan dan di sisi lain mencaci maki dan menstigma orang atau kelompok lain yang berseberangan dengan pemikiran dan ideologi mereka sebagai liyan (the other).

Jordan Newton menyatakan gerakan organisasi transnasional melakukan upaya membawa ideologinya ke dalam konteks lokal Indonesia untuk menarik simpati dengan sejumlah penyesuaian misalnya melalui film, penggunaan simbol Indonesia, menaruh perhatian pada Pancasila dengan pemusatan ide hanya pada sila pertama (Sucahyo, 2020).

Ideologi transnasional berbasis keagamaan di Indonesia diekspresikan dalam tiga model gerakan yaitu: 1) gerakan terorisme dengan basis massa kecil; 2) gerakan moderat tanpa kekerasan yang memiliki basis massa yang cukup besar dan sebagian ada di parlemen; 3) gerakan nirkekerasan konservatif sosial yang mempromosikan kembali nilai-nilai konservatif ke dalam masyarakat.

Dalam penelitian ini, sampradaya merupakan ideologi dan organisasi transnasional yang bersifat konservatif ortodoks dengan karakteristik sebagai berikut: 1) umat berasal dari lintas agama, lintas ashram, lintas wilayah maupun lintas negara; 2) Men-Tuhan-kan guru kerohanian atau guru spiritual sebagai bhagawan / bhagavan atau Tuhan yang Maha Esa; 3) hanya tunduk pada tujuan dan perintah dari garis organisasi perguruan spiritual (parampara) bukan pada tujuan negara; 4) merupakan komunitas yang hidup ekslusif menganut ajaran puritanisme abad pertengahan (abad ke-15) yaitu menekankan pada kualifikasi hidup yang murni sesuai dengan aturan perguruan; 5) memiliki badan pemerintahan sendiri di luar negeri 6) tujuan dari ideologi dan organisasi sampradaya adalah mengubah tatanan sosial, identitas budaya, nilai dan norma agama Hindu sesuai dengan garis kebijakan organisasi.

Indianisasi agama Hindu di Bali dalam rasionalisasi dan penyesuaian dengan Hindu transnasional ditujukan untuk merestorasi Hindu warisan India. Namun, pada kenyataannya mencabut kaum reformis Bali dari akar keagamaan. Kaum reformis berusaha mengganti Hindu di Bali agar lebih universal untuk menandingi agama-agama kitab dengan meninggalkan praktik leluhur, menggeser etika, bakti, ritualisme dan praktik tradisi (ortopraksi 
) menjadi ketaatan pada peraturan, ajaran resmi dan fundamentalistik (ortodoksi) neo-Hindu yang sejatinya asing bagi mereka (Deta, 2021).

Pada Hare Krishna ISCKON, Caitanya Mahaprabhu yang lahir pada 18 Februari 1458 di Nadiya Benggala dipuja sebagai Tuhan yang Maha Esa. Namun dalam propagandanya, terjadi manipulasi dilakukan dalam penyebaran buku Bhagawadgita versi Srila Prabhupada kepada masyarakat seolah Caitanya Mahaprabu adalah Krishna dalam epos Mahabarata dan tokoh dalam, Bhagawadgita. Padahal dalam kenyataanya, ISCKON telah menyesatkan masyarakat dengan memanipulasi seolah yang dipuja Sri Krishna (putra dari Devaki) dalam Epos Mahabarata, padahal yang dipuja adalah Krishna Caitanya Mahaprabu (putra dari Srimati) (Gayatri, 2007).

Selain itu juga ditemukan manipulasi berupa penyesatan pikiran terhadap teks dalam Bhagawadgita. Dalam Bhagawadgita Menurut Aslinya karangan Srila Prabupada ini ditemukan sejumlah teks sansekerta diubah sesuai dengan opini atau pandangan pribadi Srila Prabhupada (Pandya, 2021). Keberadaan ISKCON di berbagai negara termasuk Amerika, Rusia, Inggris, Hungaria, Australia juga ditentang keabsahan organisasiya, pengikutnya dituding berperilaku seperti pengemis, membuat keributan dengan kirtan, menyebarkan superioritas kontroversial dari guru-guru mereka (ISKCON, 2020).

Governing Body Commission/GBC merupakan badan pemerintah ISKCON dan manajerial tertinggi yang berkedudukan di Amerika. Komunitas ISKCON membangun proyek perkampungan eksklusif khusus bhakta Hare Krishna bernama Gita Nagari di Lampung. Model diaspora budaya abad ke-15 baik cara dan gaya hidup dari masyarakat Benggala (sekarang disebut Bangladesh) ini diadopsi dikembangkan secara nasional melalui agenda nasional ISKCON. Diaspora budaya Benggala inilah yang dianggap sebagai kualifikasi utama bagi nilai kehidupan keagamaan yang murni sesuai veda.

Internalisasi ajaran dilakukan secara halus atau manipulatif dengan memperkenalkan film yang berkaitan dengan ajaran Hare Krishna seperti film Radha Krishna di ANTV dan menyusupkan ajaran ke dalam buku Pendidikan agama di sekolah-sekolah secara nasional. Meskipun pada akhirnya, menteri agama, Fahrul Rosi menegaskan telah melakukan merevisi buku-buku pelajaran agama Hindu yang sebelumnya memuat ajaran sampradaya sesuai dengan permohonan Gubernur Bali, I Wayan Koster (Alt, 2020).

\section{PENUTUP}

Dari fenomena dan dinamika sosial yang terjadi, hasil penelitian ini menunjukkan dampak propaganda dan aksi dari Gema Hindu yaitu:1) bertujuan mendesak PHDI mencabut surat pengayoman untuk sampradaya Hare Krishna ISKCON, Sai Baba dan sampradaya lainnya; 2) berhasil mendapat simpati secara luas dengan adanya dukungan Gubernur, DPRD, Majelis Desa Adat dan PHDI Provinsi Bali dan masyarakat Hindu secara nasional 3) menghasilkan Surat Keputusan Bersama (SKB) PHDI Provinsi Bali dan MDA Provinsi Bali; 4) menghasilkan tindakan penegakan hukum preemtif, preventif dan represif dalam pencegahan penistaan agama dan fundamentalisme serta radikalisasi agama di PHDI dan desa adat sebagai bagian dari partisipasi masyarakat dalam pertahanan NKRI dan ideologi Pancasila. 


\section{DAFTAR PUSTAKA}

Adiwilaga, R. 2017. Puritanisme dan Fundamentalisme Dalam Islam Transnasional serta Implikasinya terhadap Pancasila sebagai Ideologi Bangsa. Jurnal of Governance volume 2, issue 1.

Aksa. 2017. Gerakan Islam Transnasional: Sebuah Nomenklatur, Sejarah dan Pengaruhnya di Indonesia. Yupa: Historical Studies Journal, 1 (1), Hal. 1-14.

Alt. 2020. Menag: Buku Pelajaran Agama Hindu memuat Ajaran Sampradaya Sudah Direvisi. Pos Bali 20 Desember 2020.

Ansharulloh, H. 2018. Apropiasi Budaya dan Ketimpangannya. Suakaonline.com.

Artaya. 2020. Audiensi PHDI dengan PAKEM Bali Bahas SK Jaksa Agung 107/1984 Dorong Dialog Tuntaskan Polemik Hare Krishna. Atnews 9 September.

Bali, N. 2020. Forum Taksu Bali Minta Keluarkan Hare Krishna-Kemarin Temui Pimpinan Dewan di Wantilan DPRD Bali. Nusa Bali, 10 November.

Bali, P. 2020. DPRD Bali Rekomendasi ‘Bubarkan’ Hare Krishna. Bali Post, 31 Oktober 2020.

Bali, T. 2020. Setelah Klungkung, Massa Forkom Taksu Bali Juga Gelar Demo Terkait Pernyataan AWK di Renon. Bali Tribune Bali 3 November.

Balinetizen. 2020. AWK dipukul oleh Massa Aksi di Kantor DPD Bali. Balinetizen 28 Oktober.

BBN. 2021. MDA Bali Dukung Dan Siap Perjuangkan Tindakan Tegas Desa Adat Kesiman Tutup Ashram Krishna Balaram. Beritabicaranetwork 25 April.

Budiasa, I. M. 2016. Tindakan Komunikatif Komunitas Veda Phosana Ashram Badung dalam Ritual Agni Hotra. Jurnal Penelitian Agama Vidya Samhita II(2), hal. 91-98.

BW. Ideologi Transnasional Tidak Sesuai NKRI Harus Diberangus". Beritasatu.com 10 Mei 2017.

Christianto, H. 2013. Arti Penting UU No 1/PNPS/1965 Bagi Kebebasan Beragama-Kajian Putusan Mahkamah Konstitusi Nomor 140/PUU-VII/2009. Jurnal Yudisial Vol 6 No 1 Hal.1-16.

Deta, K. U. 2020. Agama Hindu dan Adat Bali: rekognisi dan Kontestasi. crcs.ugm.id diakses tanggal 2 Mei 2020.

Devita, R. 2020. Soal Sampradaya, PHDI dan MDA Bali Keluarkan Keputusan Bersama. Bali Post 16 Desember.

Dewata, B. 2020. Gubernur Bali Sambut Baik Keputusan Pembatasan Kegiatan Pengembanan Ajaran Sampradaya Non-Dresta Bali. Beritadewata.com 17 Desember.

Dwiana, R. 2013. Mobilisasi Massa dalam Era Network Society. Jurnal Pekommas Vol 2 no 3, 2013 Hal.155-162.

Fadhil. 2014. Gerakan New Age-Agama Gado-Gado". Tempo 19 Februari.

Febryani, A. 2020. Nilai-Nilai Multikulturalisme dan Identitas legal dalam Kehidupan Umat Sikh Punjabi di Kota Medan. Prosiding Seminar Nasional Pendidikan Antropologi (Senaspa) Medan Hal. 200-211.

Gayatri, I. A. 2007. "Sistem Religi Sampradaya Kesadaran Krishna Indonesia." Tesis. Denpasar: Program Pascasarjana Universitas Udayana.

Haryani, E. 2016. Menebar Spritualitas, Menjaga Budaya: Peran Rohaniawan Asing Dalam Dinamika Kehidupan Keagamaan Di Bali. Jurnal Multikultural \& Multi Religius Vol 15 No 2.

ISKCON. 2021. Surat Edaran Tentang Penyelarasan Interaksi Sosial. diakses dari Visit ISKCON. id: www.iskcon.id pada 4 Mei.

Killian, L. M. 2020. Social Movement. Encyclopedia Britannica, https://www.britannica.com/topic/ social-movement. diakses pada 29 April.

Klungkung, P. 2020. Dengan Atribut Poleng Massa Dari Nusa Penida Gelar Aksi Damai di Tempat Sakral. Klungkung, Bali. Pemkab Klungkung, 3 November.

Kompas. 2021. Oknum Sulinggih di Bali Diduga Cabuli Perempuan Bersuami. Kompas 24 Maret. 
Kumparan. 2017. Wawancara Khusus Ranjit Singh, Pemuka Agama Sikh di Indonesia. Jakarta, Indonesia. Kumparan 9 Mei 2017.

Mds. 2021. Ketua Dewan Dukung Aksi Tutup Ashram di Padanggalak". Nusa Bali, 20 April.

M.Nuh, N. 2017. Sai Studi Group Indonesia (SSGI) di Jakarta: menebar Cinta Kaasih dalam Kehidupan Keagamaan. I. N. Segara (ed.), Dimensi Tradisional dan Spiritual Agama Hindu hal 49-86. Jakarta: Puslitbang Bimas Agama dan Layanan Keagamaan .

Muhammad, H. 2020. Ideologi Transnasional. https://www.huseinmuhammad.net/ideologitransnasional/ diakses pada 2 Mei 2021.

Mustofa, A. 2020. Di Depan Massa, Taksu Bali Dwipa Tuntut PHDI Bubarkan Hare Krishna. Radar Bali Jawa Post, 3 Agustus 2020.

Mustofa, A. 2020. Gubernur Koster Ikut Batasi Ajaran Sampradaya Non-Dresta Bali. Radar Bali Jawa Post, 3 November 2020.

Mustofa, A. 2021. LBH Bali Sebut Penutupan Ashram Krishna Balaram Langgar Hukum dan HAM. Denpasar, Bali. Radar Bali Jawa Post, 22 April.

NV. 2020. Gubernur Koster Larang Bendesa Ikut Sampradaya. Nusa Bali,19 Agustus.

Padipto Bhagaskoro, R. U. 2019. Pancasila dalam Interaksi Kearifan Lokal dan Ideologi Transnasional. Jurnal Inovasi Ilmu Sosial dan Politik, Vol. 1(2):112, DOI:10.33474/jisop.v1i2.4806.

Pandya, M. P. 2021. Hare Krishna Tidak Bersumber Pada Bhagawadgita. Media Hindu, Edisi Maret No. 203 Hal. 59.

Prabhupada, S. 2014. Srila Prabhupada says "we are not Hindus". Amerika. diakses pada 2 Mei 2021.

Rahmayunita, H. 2020. Massa Geruduk Kantor DPD Bali Teriak Turunkan AWK. Suara Bali, 3 November.

Sucahyo, N. 2020. Ideologi Islam Transnasional dan Transformasi ke Konteks Lokal”. VoaIndonesia. com, 21 Oktober.

Sukkanah, U. 2017. Harmoni Kehidupan Melalui Etika dan Moralitas dalam SAKKHI. Dalam Dimensi Tradisional dan Spiritual Agama Hindu. Jakarta: Badan Litbang dan Diklat Kementerian RI.

Tribun. 2021. PHDI Bali: Diksa Massal Bisa Dilakukan Asal Satu Nabe Satu Sisya. Tribun Bali.com, 21 Maret.

VPA. 2018. Mengenal Veda Poshana Ashram. diakses dari Veda Poshana-Ashram.org. pada 2 Mei.

Winata. 2021. Soal Penutupan Ashram Krishna Balaram di Kesiman, MDA dan PHDI Akhirnya Bersikap. Bali Post, 21 April. 